\title{
Ionic Composition of Wheat in Response to Silicon Application under Saline Growth Environment
}

\section{Mukkram Ali Tahir ${ }^{1}$, Noor-us-Sabah $^{1 *}$, Ghulam Sarwar ${ }^{1}$, Muhammad Aftab ${ }^{2}$,Abdul Moeez ${ }^{1}$, Muhammad Zeeshan Manzoor ${ }^{1}$ and Aneela Riaz ${ }^{3}$}

${ }^{1}$ Department of Soil and Environmental Sciences, College of Agriculture, University of Sargodha, Sargodha, Pakistan; ${ }^{2}$ Institute of Soil Chemistry and Environmental Sciences, AARI, Faisalabad, Pakistan; ${ }^{3}$ Soil Bacteriology Section, AARI, Faisalabad, Pakistan.

Abstract | Salinity is very common threatening issue regarding growth and yield of dry regions of the world and likewise in Pakistan. Silicon role in plant growth and especially strengthening of plant defence system is well documented particularly upon exposure to salt stress. Present research was performed using wheat variety Punjab-2011 with Randomized Complete Block Design (RCBD) under field conditions using three treatments and each replicated three times. Treatments were wheat florae were developed in plots having normal soil $(\mathrm{EC}=2.32 \mathrm{dS} / \mathrm{m})$ and salty soil $(4.93 \mathrm{dS} / \mathrm{m}) . \mathrm{Si}$ as phosphate industry waste was applied @ 0, 50 and $100 \mu \mathrm{g} \mathrm{Si} / \mathrm{g}$ soil. Results showed that application of $\mathrm{Si}$ reduced the adverse impact of salinity and significantly enhanced the nutrients status of wheat plant. Under normal soil conditions, sodium ( $\mathrm{Na}$ ) concentration $(5.63 \mathrm{mg} / \mathrm{g})$, potassium $(\mathrm{K})$ concentration $(9.20 \mathrm{mg} / \mathrm{g}), \mathrm{Na} / \mathrm{K}$ ratio $(1.60 \mathrm{mg} / \mathrm{g})$, relative water contents $(56.49 \%)$ and total chlorophyll contents $(2.74 \mathrm{mg} / \mathrm{g})$ were observed when maximum concentration of Si was applied i.e. $100 \mu \mathrm{g} \mathrm{Si} / \mathrm{g}$ and least was recorded when no Si was applied. Similarly, under saline soil conditions, maximum sodium concentration $(6.72 \mathrm{mg} / \mathrm{g})$, potassium concentration $(16.6 \mathrm{mg} / \mathrm{g}), \mathrm{Na} / \mathrm{K}$ ratio $(2.5 \mathrm{mg} / \mathrm{g})$, relative water contents $(53.63 \%)$ and total chlorophyll contents $(2.50 \mathrm{mg} / \mathrm{g})$ were observed when maximum concentration of $\mathrm{Si}$ was applied i.e. $100 \mu \mathrm{g} \mathrm{Si} / \mathrm{g}$.

Received | March 09, 2021; Accepted | March 28, 2021; Published | June 21, 2021

*Correspondence | Noor-Us-Sabah, Department of Soil and Environmental Sciences, College of Agriculture, University of Sargodha, Sargodha, Pakistan; Email: soilscientist.uca@gmail.com

Citation | Tahir, M.A., N.U. Sabah, G. Sarwar, M. Aftab, A. Moeez, M.Z. Manzoor and A. Riaz. 2021. Ionic composition of wheat in response to silicon application under saline growth environment. Pakistan Journal of Agricultural Research, 34(3): 510-516.

DOI | https://dx.doi.org/10.17582/journal.pjar/2021/34.3.510.516

Keywords | Salinity, Wheat, Silicon, Sodium, Potassium, Chlorophyll

\section{Introduction}

Salinity is very common threatening issue regarding growth and yield of dry regions of the world (Sarah et al., 2020). Wheat is among widely consumed cereal and one of the victims of salinity stress. Growth and yield of plants is affected by salinity stress due to disturbance of various processes involved in plant physiology and biochemistry (Zeng and Shannon, 2000). When plants are exposed to saline environment, disturbance in turgidity, enzymes functioning and photosynthesis apparatus of plants take place (Sarah et al., 2020). Similarly, disturbance in opening and closing of stomata and resultantly in net photosynthesis rate also occur due to higher salt uptake by plants exposed to salinity (Rozeff, 1995; Lingle and Weigand, 1997). Cheesman (1988) also stated a reduction in cell turgidity and photosynthesis due to closure of stomata as a result of exposure of roots to saline environment. Lowering 
of chlorophyll content is possible reason behind reduced photosynthesis. Similarly, translocation and formulation of photosynthate is also disturbed due to salinity stress.

Silicon role in plant growth and especially strengthening of plant defence system is well documented particularly upon exposure to salt stress (Liang et al., 1996). External supply of Si to plants under stress resulted in improvement of plant growth particularly in graminae family like wheat (Liang et al., 1996). Silicon ( $\mathrm{Si}$ ) was described to lessen the salinity effect upon wheat and on other varietals as well. So, to see the outcome of Si a trial was conducted by Saqib et al. (2008), reduce plant uptake of $\mathrm{Na}+$ root distribution of salt-tolerant wheat genotype is due to silicon. Low $\mathrm{Na}^{+}$levels in shoot and increased $\mathrm{K}^{+}: \mathrm{Na}^{+}$ ratio in buds caused enhanced plant development. The silicon caused increase in cell wall capacity to bind $\mathrm{Na}+49 \%$ in SARC-1 and 37\% in 7-Cerros under salt stress to $87 \%$ in SARC-1 and 79\% in Cerros-7 under Salinity + Silicon. This might also lead to lower $\mathrm{NaCl}$ concentrations. The amount of Glutathione, a vital antioxidant in plant, was augmented because adding of silicon under salty condition. The cultivar resistant SARC-1 was less responsive to silicon in fresh weight, up $39 \%$ equated by a $49 \%$ rise in 7 -Cerros and fresh root weightiness, up $12 \%$ compared to $22 \%$ in 7-Cerros. This determines Silicon has enhanced the development of buds to resist salinity as well as genotype of saline-sensitive wheat by reducing the $\mathrm{Na}^{+}$ion absorption of the plant and harvesting the plant, $\mathrm{Na}+$ root dissemination along with improving level of Glutathione. Si may have good detoxification of $\mathrm{Na}^{+}$inside the plant by increasing the $\mathrm{Na}^{+}$link of the cellular wall too.

Ali et al. (2012) assessed growing processes of two wheat genotypes (Auqab-2000 and SARC-5) that differ in tolerance to salinity of silicon applied in saline environments. Plants were grown in vessels filled with soil $(\mathrm{EC}=1.16 \mathrm{dS} / \mathrm{m})$ and salt affected soils $(\mathrm{EC}=10 \mathrm{dS} / \mathrm{m})$. Silicon was applied in soil at the rate of 0,50 and $130.0 \mu \mathrm{g} \mathrm{Si} /$ gram using the source in the form of calcium silicate. The plants were collected at their prime and various physical and biochemical constraints were noted. Severe salinity pressure $(\mathrm{P}<0.01)$ decreased dehydrated material production and grain productivity for each wheat genotype. Though, the decrease was low in SARC5 as compared to Auqab-2000. The use of silicon in the centre of growth noticeably $(\mathrm{p}<0.01)$ resulted in improved dry material and grain produce for each genotype grown either in normal conditions or in salt water. Potassium extent was amplified considerably in plants grown with $\mathrm{Si}$ in salt affected soil. The concentration of potassium was lower in saline plants as compared to those plants which are grown in normal soils only in plants containing Silicon. The uptake of sodium was higher in plants developed in salinity, but application of $\mathrm{Si}$ considerably reduced $\mathrm{Na}$ absorption, as a result there was a substantial rise in potassium: sodium $(\mathrm{K}: \mathrm{Na})$ proportion in buds. The sodium extent in the buds has a substantial harmful link ( $r>0.81, p<0.01)$ with dehydrated material of shoot of the two genotypes, however, the shoot dry matter (SDM) was lower in Auqab-2000. The increase in $\mathrm{Na}$ intensity due to salinity was reduced a lot in plants that received $\mathrm{Si}$ in the root surroundings. The Si concentration in the shoot is mostly associated with the shoot $\mathrm{K}$ extent $(\mathrm{r}=0.83, \mathrm{P}<0.01)$ and negative to $\mathrm{Na}$ concentration of the shoot $(\mathrm{r}=0.57, \mathrm{P}<0.05)$. Increased levels of potassium and lowered sodium absorption and displacement may be one of the likely mechanisms to increase tolerance of salinity by applying $\mathrm{Si}$ in wheat.

Tuna et al. (2008) also reported the positive effects of $\mathrm{Si}$ application in wheat under salinity stress. They reported that plants grown at a rate of 100 $\mathrm{mg}$ sodium chloride produced dehydrated material and chlorophyll content lower than those that did not contain sodium chloride. The permeability of membrane and proline amount increased in leaves by adding $100 \mathrm{~mL}$ Sodium Chloride and the increases were declined by treatment of Silicon. Sodium extent in plant's tissue expanded in two shoots and foundations of plant in their treatments with high $\mathrm{NaCl}$ and Silicon brought down essentially amount of Sodium in the two buds and root. Among both bread and durum wheat the previous was more tolerant to saltiness than the later. $\mathrm{Na}$ build-up in the root point out a likely system where the bread wheat adjusts with salts in roots or might specify a mechanism of reserve of Sodium transfer to the leaves. Both absorptions of calcium and potassium were lesser in plants that were developed on higher sodium chloride extent than those in control treatment. These applications were enhanced due to two Si treatments in each of the shoot and root but kept on below control values in maximum situations. 
Therefore, the present research trail was executed in order to justify the impact of exogenous application of Silicon on the growth of wheat and to estimate the combined effect of exogenous Silicon application on salinity in root zone and on the growth and development of wheat crop.

\section{Materials and Methods}

The research was performed in the research area of Department of Soil and Environmental Science during the summer, 2018 in University College of Agriculture, University of Sargodha, Sargodha, Pakistan. In the present study growth established of wheat variety Punjab-2011 was performed on the normal and saline field. The research was carried out in Randomized Complete Block Design (RCBD) under divided plot arrangements through nine treatments and each replicated three times. The net plot dimensions were $4 \mathrm{~m} \times 3 \mathrm{~m}$ having strips spacing of $75 \mathrm{~cm}$ and distance between each plant was $25 \mathrm{~cm}$. The experimentation included following treatments: Wheat was established in plots with normal soil $(\mathrm{EC}=2.32 \mathrm{dS} / \mathrm{m})$ and salt affected soil $(4.93 \mathrm{dS} / \mathrm{m})$. $\mathrm{Si}$ as phosphate industry waste was applied @ $\mathrm{T}_{1}=$ $0, \mathrm{~T}_{2}=50$ and $\mathrm{T}_{3}=100 \mu \mathrm{g} \mathrm{Si} / \mathrm{g}$ soil. Collection of soil samples were done before and after crop harvest. Analysis of various parameters of soil was done using procedures described in handbook 60 of U.S Laboratory Staff (1954). Various physio-chemical traits of soil before cultivation are revealed in Table 1 . Data of following constraints were noted using their accepted techniques:

Table 1: Soil physio-chemical characteristics before crop sorwing.

$\begin{array}{llll}\text { Characteristics } & \text { Unit } & \text { Normal Soil } & \text { Saline Soil } \\ \text { EC } & \mathrm{dS} \mathrm{m}^{-1} & 2.32 & 4.93 \\ \text { Soil pH } & - & 7.9 & 8.62 \\ \text { Organic matter } & \% & 0.5 & 0.3 \\ \text { Total Nitrogen } & \% & 0.04 & 0.02 \\ \text { Available P } & \mathrm{ppm} & 7.75 & 5.6 \\ \text { Extractable K } & \mathrm{ppm} & 130.5 & 110.5 \\ \text { Available } \mathrm{Si} & (\mathrm{mg} / \mathrm{kg} \text { soil) } & 30 & 25 \\ \text { Total } \mathrm{Si} & (\mathrm{mg} / \mathrm{kg} \text { soil }) & 229 & 205\end{array}$

To compute the value of water contents in leaves samples, fresh and healthy samples were collected randomly from each treatment and placed in sealed plastic bag. With 2 hours of cutting of leaf fresh weight was calculated and then at room temperature these samples were dipped into distilled water for 12 hours to calculate turgid weight. After 12 hours turgid weight was calculated very carefully. To calculate dry weight, leaves samples were over dried at $70^{\circ} \mathrm{c}$ for 3 three day and then weight was determined.

Final value was calculated with help of formula which was recommended by Turner (1986).

$$
R L W C(\%)=(F W-D W) /(T W-D W) \times 100
$$

Todetermine the contents of chlorophyllapproximately $1.0 \mathrm{~g}$ of the leaf sample was homogenized in mortar and pestle after cutting into pieces by using $80 \%$ acetone. At $3000 \mathrm{rpm}$ these grounded samples were centrifuged by adding $25 \mathrm{ml}$ acetone for 15 mints. At 645 and $663 \mathrm{~nm}$ density of clear solution was measured against blank in Shimadzu double beam spectrophotometer.

\section{Contents of chlorophyll $\mu \mathrm{g} / \mathrm{mL}=20.2 x$ density $(645 \mathrm{~nm})$ plus $8.02 \times$ density $(663 \mathrm{~nm})$}

The noted data were statistically analyzed by using Statistix 8.1 analysis of variance (ANOVA) procedure and significant of treatments means were compared using Tukey's (HSD) test at 5\% probability level (Steel et al., 1997).

\section{Results and Discussion}

\section{Sodium concentration $(\mathrm{mg} / \mathrm{g})$}

The data concerning in Figure 1 displayed that influence of silicon amendment on sodium concentration of wheat crop under normal and salt affected soil. A significant impact of silicon nutrition was detected on sodium concentration of wheat plants. The maximum sodium concentration $(11.85 \mathrm{mg} / \mathrm{g})$ of wheat was observed where no silicon $\left(\mathrm{T}_{4}=0 \mu \mathrm{g} \mathrm{Si} / \mathrm{g}\right)$ was applied under salt affected soil surroundings while the lowest sodium extent $(5.63 \mathrm{mg} / \mathrm{g})$ was observed at high silicon level $\left(\mathrm{T}_{3}=100 \mu \mathrm{g} \mathrm{Si} / \mathrm{g}\right)$ under normal soil conditions. The medium silicon treatment level $\left(\mathrm{T}_{2}=50 \mu \mathrm{g} \mathrm{Si} / \mathrm{g}\right)$ was able to produced 6.01 and 7.10 $\mathrm{mg} / \mathrm{g}$ sodium concentration of wheat under normal and salt stressed soil circumstances respectively. However, amongst all the tested levels of silicon, the 0 $\mu \mathrm{g} \mathrm{Si} / \mathrm{g}$ was produced higher sodium concentration in wheat. Our outcomes were supported with outcomes of Ali et al. (2014) who indicated that the uptake of 
sodium was higher in plants developed in salinity, but application of Si considerably reduced $\mathrm{Na}$ absorption. This research also followed the analyses of Saqib et al. (2008) and Tahir et al. (2006) who determined that silicon has boosted the development of buds to resist salinity as well as genotype of saline-sensitive wheat by reducing the $\mathrm{Na}^{+}$absorption of the plant. The silicon ( $\mathrm{Si}$ ) may have good detoxification of $\mathrm{Na}^{+}$ inside the plant by increasing the $\mathrm{Na}^{+}$link of the cellular wall too.

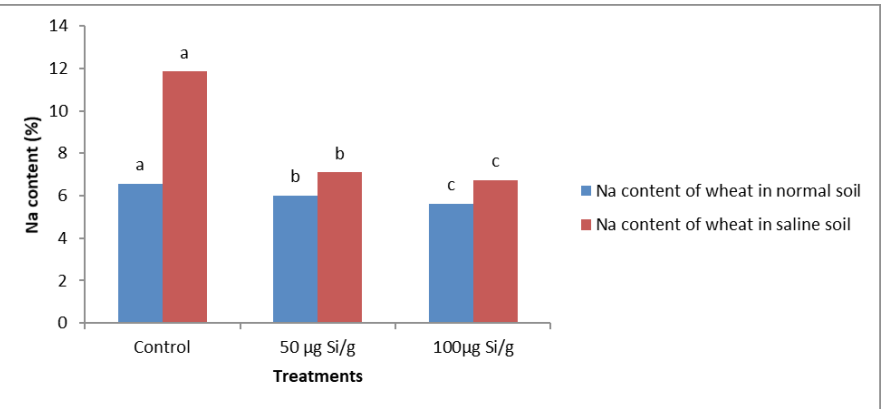

Figure 1: Impact of various silicon concentrations on $\mathrm{Na}$ content of wheat shoot (\%) under normal and salt affected soils.

\section{Potassium concentration (\%)}

Influence of different silicon concentrations on potassium concentration of wheat sown under normal and salt stressed soil conditions is showed in Figure 2. The data specified that various concentrations of silicon significantly influence the potassium concentration of wheat. In case of wheat, among all the silicon concentrations the highest potassium concentration $(9.20 \mathrm{mg} / \mathrm{g})$ was noted with $100 \mu \mathrm{g}$ $\mathrm{Si} / \mathrm{g}$ under normal soil conditions. The minimum potassium concentration $(5.0 \mathrm{mg} / \mathrm{g})$ was recorded in plots where silicon was applied at $0 \mu \mathrm{g} \mathrm{Si} / g$ under salt affected soil conditions. The medium treatment level $\left(\mathrm{T}_{2}=50 \mu \mathrm{g} \mathrm{Si} / \mathrm{g}\right)$ of silicon was produced 8.60 and $11.7 \mathrm{mg} / \mathrm{g}$ of potassium concentration under normal and salt affected soil, respectively. It is also showed that application of $100 \mu \mathrm{g} \mathrm{Si} / \mathrm{g}$ was highly efficient in producing the greater potassium concentration of wheat under both soil conditions (normal and salt affected). The results of this research also resembled with the experiment of Saleh et al. (2017) and Liang et al.1996, which states that $\mathrm{Si}$ can improve potassium absorption $(\mathrm{K})$ and prevent sodium absorption $(\mathrm{Na})$ by salinized barley, hence reducing salt poisonous in barley and enhancing tolerance of plants to salts.

\section{$\mathrm{Na} / \mathrm{Kratio}(\mathrm{mg} / \mathrm{g})$}

It is apparent from the data existing in Figure 3 that several concentrations of silicon have varying impact on the $\mathrm{Na} / \mathrm{K}$ ratio in wheat crop. Both tested crops showed considerable response to different concentrations of silicon under normal and salt affected soil. It was noticed that maximum $\mathrm{Na} / \mathrm{K}$ ratio $(1.60 \mathrm{mg} / \mathrm{g})$ was documented with $100 \mu \mathrm{g} \mathrm{Si} / \mathrm{g}$ silicon concentration under normal soil conditions. However, the minimum $\mathrm{Na} / \mathrm{K}$ ratio $(0.40 \mathrm{mg} / \mathrm{g})$ was recorded with $0 \mu \mathrm{g} \mathrm{Si} / \mathrm{g}$ silicon concentration under salt affected soil conditions. The application of $50 \mu \mathrm{g}$ $\mathrm{Si} / \mathrm{g}$ silicon concentration produced 1.40 and 1.60 $\mathrm{mg} / \mathrm{g} \mathrm{Na} / \mathrm{K}$ ratio under normal and salt affected soil conditions respectively. It was also revealed from the data that $100 \mu \mathrm{g} \mathrm{Si} / \mathrm{g}$ silicon concentration was much better than 50 and $0 \mu \mathrm{g} \mathrm{Si} / g$ concentrations in case of $\mathrm{Na} / \mathrm{K}$ ratio in wheat crop. This trial also resembled with the study of Saleh et al. (2017) and Ali et al. (2014) which states that $\mathrm{Si}$ supplements in solution culture enhanced wheat development and $\mathrm{K}+/ \mathrm{Na}+$ with $\mathrm{Na}+$ reduction and heightened $\mathrm{K}+$ absorption. An accompanying enhancement was seen in the development of the shoot. However, by Si treatment root growth remained unchanged.

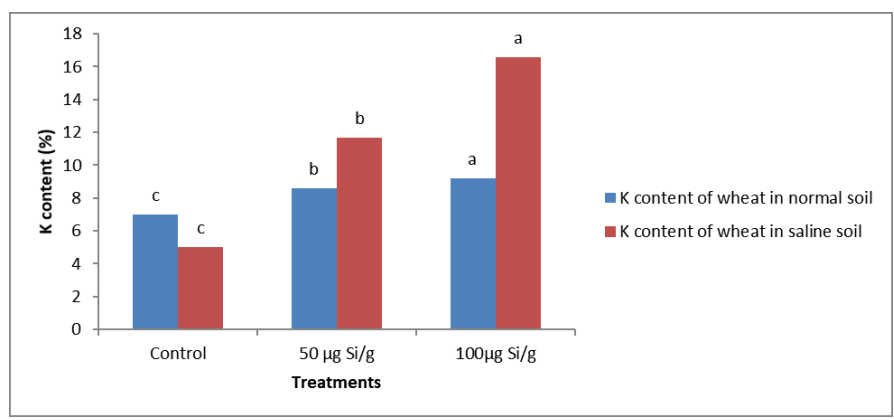

Figure 2: Impact of various silicon concentrations on $K$ content of wheat shoot (\%) under normal and salt affected soils.

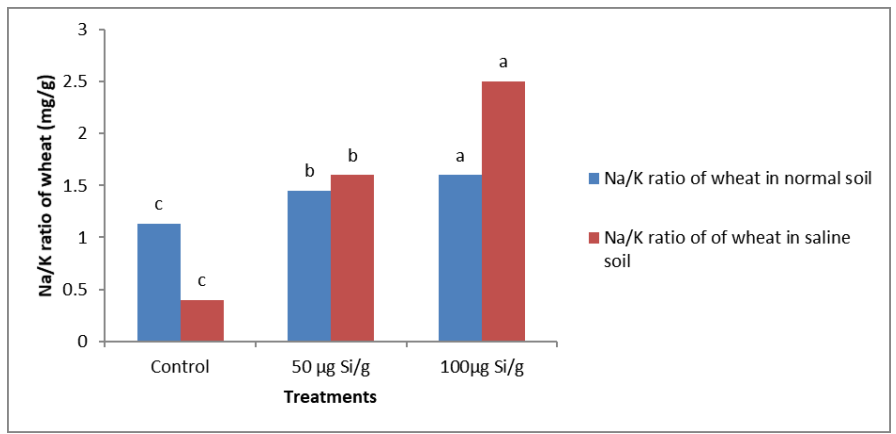

Figure 3: Impact of various silicon concentrations on $N a / K$ ratio of wheat $(\mathrm{mg} / \mathrm{g})$ under normal and salt affected soils.

\section{Relative water contents (\%)}

The data concerning Figure 4 demonstrated that influence of silicon adjustment on relative water contents of wheat in normal and salt affected soil. A significant impact of silicon nutrition was detected on relative water contents of wheat. The maximum relative 
water contents (56.49\%) of wheat was observed at high silicon level $\left(\mathrm{T}_{3}=100 \mu \mathrm{g} \mathrm{Si} / \mathrm{g}\right)$ under normal soil conditions while the lowest relative water contents (41.37\%) was observed where no silicon $\left(\mathrm{T}_{4}=0 \mu \mathrm{g}\right.$ $\mathrm{Si} / \mathrm{g}$ ) was applied under salt affected soil conditions. The medium silicon treatment level $\left(\mathrm{T}_{2}=50 \mu \mathrm{g} \mathrm{Si} / \mathrm{g}\right)$ was able to produce 47.40 and $46.87 \%$ relative water contents of wheat under normal and salt affected soil conditions, respectively. Amongst all the tested levels of silicon, the $100 \mu \mathrm{g} \mathrm{Si} / \mathrm{g}$ was found more effective in producing higher relative water contents of wheat. The results of this research also matched with the experiment of Sattar et al. (2020) and Gong et al. (2006) who stated that the potential of water in wheat crop subjected to stress on which silicon is applied could maintain to a greater magnitude as compared to with plants subjected to stress without silicon amendments, signifying that silicon can enhance the water status of wheat plants throughout any stress.

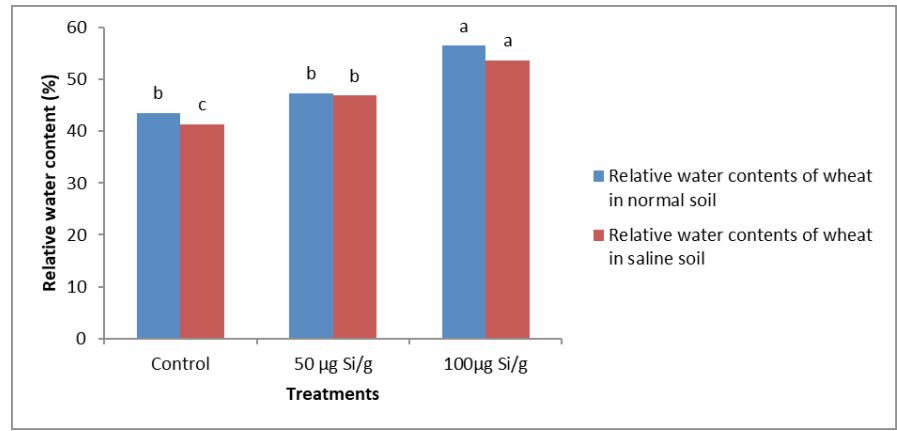

Figure 4: Impact of various silicon concentrations on relative water content of wheat (\%) under normal and salt affected soils.

\section{Total chlorophyll contents $(m g / g)$}

It is obvious from the figures existing in Figure 5 that various concentrations of silicon have changing impact on the total chlorophyll contents of wheat crop. Substantial response was shown by wheat to different concentrations of silicon under normal and salt affected soil. In wheat crop, maximum chlorophyll contents $(2.50 \mathrm{mg} / \mathrm{g})$ were perceived with $100 \mu \mathrm{g} \mathrm{Si} / \mathrm{g}$ silicon concentration under normal soil conditions. However, the minimum chlorophyll contents $(1.90 \mathrm{mg} / \mathrm{g})$ were recorded with $0 \mu \mathrm{g} \mathrm{Si} / \mathrm{g}$ silicon concentration under salt affected soil conditions. The application of 50 $\mu \mathrm{g} \mathrm{Si} / \mathrm{g}$ silicon concentration produced 2.02 and $2.05 \mathrm{mg} / \mathrm{g}$ chlorophyll contents under normal and salt affected soil environments respectively. It was also revealed from the data that $100 \mu \mathrm{g} \mathrm{Si} / \mathrm{g}$ silicon concentration was much better than 50 and $0 \mu \mathrm{g}$ $\mathrm{Si} / \mathrm{g}$ concentrations in case of chlorophyll contents of wheat. This research also related to the experiment of Saleh et al. (2017) and Al-aghabary et al (2005), their outcomes showed that silicon to some extent corresponds to increases the tolerability of tomato plants to sodium chloride salinity by increasing CAT and SOD enzyme function, chlorophyll content and PSII's photochemical efficiency.

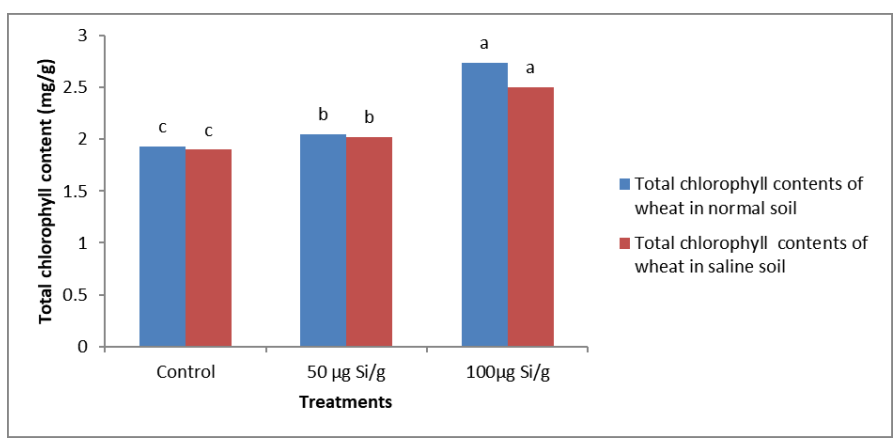

Figure 5: Impact of various silicon concentrations on total chlorophyll content of wheat (\%) under normal and salt affected soils.

\section{Conclusions and Recommendations}

Silicon application improved growth of wheat and under saline field conditions. Growth enhancement in wheat by application of silicon was more noticeable under salt stress. The amended growth by $\mathrm{Si}$ under salinity was credited to abridged $\mathrm{Na}^{+}$uptake and its translocation, this increased $\mathrm{K}^{+}$uptake and increased $\mathrm{K} / \mathrm{Na}$ ratio. The incidence of pest and disease was not observed on experimental crops. In general, outcomes of the present research revealed that application of active $\mathrm{Si}$ in growth medium enhanced soil fertility, increased quantity and quality of crops and also reduced the negative impact of adverse environmental condition especially salinity in wheat.

\section{Novelty Statement}

Application of silicon can alleviate harmful effects of salts under saline growth conditions.

\section{Author's Contribution}

Mukkram Ali Tahir: Designed and supervised the study.

Noor-us-Sabah: Co-supervised the research.

Ghulam Sarwar: Assisted technically.

Muhammad Aftab: Drafting of study.

Abdul Moeez and Muhammad Zeeshan Manzoor:

Carried out the study.

Aneela Riaz: statistical analysis of data.

\section{Conflict of interest}


The authors have declared no conflict of interest.

\section{References}

Ahmad, F., T.Aziz, M.A. Maqsood,M.A.Tahir and S. Kanwal. 2007. Effect of silicon application on wheat (Triticum aestivum L.) growth under water deficiency stress. Emir. J. Food Agric., pp. 1-7. https://doi.org/10.9755/ejfa.v12i1.5170

Al-aghabary, K., Z.Zhu and Q.Shi.2005. Influence of silicon supply on chlorophyll content, chlorophyll fluorescence, and antioxidative enzyme activities in tomato plants under salt stress. J. Plant Nutr., 27(12): 2101-2115. https://doi.org/10.1081/PLN-200034641

Ali, A., S.M. Basra, J. Iqbal, S. Hussain, M.N. Subhani, M. Sarwar and M. Ahmed. 2012. Augmenting the salt tolerance in wheat (Triticum aestivum) through exogenously applied silicon. Afr. J. Biotechnol., 11(3): 642649. https://doi.org/10.5897/AJB11.3220

Broadley, M., P. Brown, I. Cakmak, J.F. Ma, Z. Rengel and F. Zhao. 2012. Beneficial elements. In: Marschner's Mineral Nutrition of Higher Plants (ed. Marschner, P.) Elsevier, Oxford, UK. pp. 249-269. https://doi.org/10.1016/B978-012-384905-2.00008-X

Cheesman, J. M. 1988. Mechanism of salinity tolerance in plants. Plant Physiol., 87:547-550.

Currie, H.A. and C.C. Perry. 2007. Silica in plants: biological, biochemical and chemical studies. Ann. Bot., 100(7): 1383-1389. https:// doi.org/10.1093/aob/mcm247

Economic Survey of Pakistan. 2018-2019. Agricultural statistics of Pakistan. Ministry of Food, Agriculture and Livestock. Government of Pakistan, Islamabad.

Gong, H.J., D.P. Randall and T.J. Flowers. 2006. Silicon deposition in the root reduces sodium uptake in rice (Oryza sativa L.) seedlings by reducing bypass flow. Plant, Cell Environ., 29(10): 1970-1979. https://doi. org/10.1111/j.1365-3040.2006.01572.x

Hajiboland, R., 2012. Effect of micronutrient deficiencies on plants stress responses. In: Abiotic stress responses in plants Springer, New York, NY. pp. 283-329. https://doi. org/10.1007/978-1-4614-0634-1_16

Hajiboland, R. and L. Cheraghvareh. 2014. Influence of Si supplementation on growth and some physiological and biochemical parameters in salt-stressed tobacco (Nicotiana rustica L.) plants.J.Sci.IslamicRepubl.Iran,25(3):205-217.

Hashemi,A.,A.Abdolzadeh and H.R.Sadeghipour. 2010. Beneficial effects of silicon nutrition in alleviating salinity stress in hydroponically grown canola, Brassica napus L., plants. Soil Sci. Plant Nutr., 56(2): 244-253. https://doi.org/10.1111/ j.1747-0765.2009.00443.x

Hussain, S., Z. Jun-hua, Z. Chu, Z. Lian-feng, C. Xiao-chuang, Y. Sheng-miao, A. B. James, H. Ji-jie and J. Qian-yu. 2017. Effects of salt stress on rice growth, development characteristics, and the regulating ways: A review. J. Integr. Agric., 16(11): 2357-2374. https://doi.org/10.1016/ S2095-3119(16)61608-8

Ibrahim, M.A., A.M. Merwad, E.A. Elnaka, C.L. Burras and L. Follett. 2016. Application of silicon ameliorated salinity stress and improved wheat yield. J. Soil Sci. Environ. Manage., 7(7): 81-88. https://doi.org/10.5897/ JSSEM2016.0571

Katyayan, A., 2005. Fundamentals of Agriculture. Kushal Publications and Distributors, Varanasi, Uttar Pradesh, pp. 10-11.

Liang, Y., Q. Shen, Z. Shen and T. Ma. 1996. Effects of silicon on salinity tolerance of two barley cultivars. J. Plant Nutr., 19(1): 173-183. https://doi.org/10.1080/01904169609365115

Lingle, S. E. and C. L.Wiegand.1996. Growth and yield responses ofsugarcane to saline soil: II. Sucrose biochemistry in individualinternodes. In: Proceedings of the Inter American Sugarcane Seminars. Miami. USA. p. 93-102.

Lou, W.P., L.H. Wu, H.Y. Chen and Z.W.Ji. 2012. Assessment of rice yield loss due to torrential rain: A case study of Yuhang Country, Zhejiang Province, China. Natl. Hazard., 60: 311-320. https://doi.org/10.1007/s11069-011-0013-4

Maas, E.V. and S.R. Grattan. 1999. Crop yield as affected by salinity. In. R.W. Skaggs and J. van Schilfgaarde (eds.), Agricultural Drainage, Agron. Monograph 38. ASA, CSSA, SSSA, Madison, WI.

Mali, M. and A.N.C. Aery. 2008. Silicon effects on nodule growth, dry-matter production, and mineral nutrition of cowpea (Vigna unguiculata). J.Plant Nutr. Soil Sci., 171(6): 835840. https://doi.org/10.1002/jpln.200700362

Masood, M.S., 2013. Wheat in Pakistan. Pakistan agriculture research council.

Mishra, C.N., K. Venkatesh, S. Kumar, S.K. Singh, 
V. Tiwari and I. Sharma. 2013. Harnessing winter wheat variability for enhancement of yield in spring wheat. Int. J. Bio-Resour. Stress Manage., 4(2): 375-377.

Nasri, R., A. Kashani, M. Barary, F. Paknejad and S. Vazan. 2014. Nitrogen uptake and utilizationefficiencyand the productivityof wheat in double cropping system under different rates of nitrogen. Int. J. Biosci., 4(4): 184-193. https://doi.org/10.12692/ijb/4.4.184-193

Rogalla, H. and V. Römheld. 2002. Role of leaf apoplast in silicon-mediated manganese tolerance of Cucumis sativus L. Plant, Cell Environ., 25(4): 549-555. https:// doi.org/10.1046/j.1365-3040.2002.00835.x

Rohani, S.K. and S. Marker. 2016. Correlation and path coefficient analysis of some quantitative traits in wheat (Triticum aestivum L.). Int. J. Multidiscipl. Res. Dev., 3(7): 15-20.

Rohanipoor, A., M. Norouzi, A. Moezzi and P. Hassibi. 2013. Effect of silicon on some physiological properties of maize (Zea mays) under salt stress. J. Biol. Environ. Sci., 7: 71-79.

Rozeff N. 1995. Sugarcane and Salinity-a review paper. Sugarcane, 5: 8-19.

Saleh, J., N. Najafi and S. Oustan. 2017. Effects of silicon application on wheat growth and some physiological characteristics under different levels and sources of salinity. Commun. Soil Sci. Plant Anal., 48(10): 1114-1122. https://doi.org /10.1080/00103624.2017.1323090

Saqib, M., C. Zörb and S. Schubert. 2008. Siliconmediated improvement in the salt resistance of wheat (Triticum aestivum) results from increased sodium exclusion and resistance to oxidative stress. Funct. Plant Biol., 35(7): 633639. https://doi.org/10.1071/FP08100

Sarah,J., Thorne, E.H. Susan and F.M.M.Maathuis. 2020. Is silicon a panacea for alleviating drought and salt stress in crops? Front. Plant Sci., pp. 11. https://doi.org/10.3389/fpls.2020.01221

Sattar, A., M.A. Cheema, A.M. Sher, M. Ijaz, A. Wasaya, T.A. Yasir, T. Abbas and M. Hussain. 2020. Foliar applied silicon improves water relations, stay green and enzymatic antioxidants activity in late sown wheat. Silicon, 12: 223-230. https://doi.org/10.1007/s12633-019-00115-7

Savvas, D., D. Giotis, E. Chatzieustratiou, M. Bakea and G. Patakioutas. 2009. Silicon supply in soilless cultivations of zucchini alleviates stress induced by salinity and powdery mildew infections. Environ. Exp. Bot., 65(1): 11-17. https://doi.org/10.1016/j. envexpbot.2008.07.004

Steel, R.G.D., J.H. Torrie and D.A. Dichey. 1997. Principles and Procedures of Statistics: A biometrical approach, $3^{\text {rd }}$ Ed. McGraw Hill Book Co., New York, USA.

Suleiman, A.A., J.F. Nganya and A. Ashraf. 2014. Correlation and path analysis of yield and yield components in some 221 Cultivars of Wheat (Triticum Aestivum L) in Khartoum State, Sudan. J. For. Prod. Ind., 3(4): 198-203.

Tahir, M.A., Rahmatullah, T. Aziz, M. Ashraf, S. Kanwal and M.A. Maqsood. 2006. Beneficial effects of silicon in wheat (Triticum aestivum L.) under salinity stress. Pak. J. Bot., 38(5): 1715-1722.

Tuna, A.L., C. Kaya, D. Higgs, B. MurilloAmador, S. Aydemir and A.R. Girgin. 2008. Silicon improves salinity tolerance in wheat plants. Environ.Exp.Bot., 62(1): 10-16.https:// doi.org/10.1016/j.envexpbot.2007.06.006

TURNER, N.C., 1986. Crop water deficits: A decade of progress. Adv. Agron., 39: I-51.

U.S. Salinity Lab. Staff. 1954. Diagnosis and improvement of saline and alkali soil. USDA. Hand book No. 60, US. Govt. Printing Office, Washington DC. 160p.

Yadav, R., S.S. Singh, N. Jain, G.P. Singh and K.V. Prabhu. 2010. Wheat production in India: Technologies to face future challenges. J. Agric. Sci., 2(2): 164-171. https://doi.org/10.5539/ jas.v2n2p164

Yan, G., X. Fan, M. Peng, C. Yin, Z. Xiao and Y. Liang. 2020. Silicon improves rice salinity resistance by alleviating ionic toxicity and osmotic constraint in an organ-specific pattern. Front. Plant Sci., 1: 260-266. https://doi. org/10.3389/fpls.2020.00260

Yeo, A.R., S.A. Flowers, G. Rao, K. Welfare, N. Senanayake and T.J. Flowers. 1999. Silicon reduces sodium uptake in rice (Oryza sativa L.) in saline conditions and this is accounted for by a reduction in the transpirational bypass flow. Plant, Cell Environ., 22(5): 559-565. https://doi. org/10.1046/j.1365-3040.1999.00418.x

Zeng, L. and M.C. Shannon. 2000. Salinity effects on seedling growth and yield components of rice. Crop Sci., 40: 996-1003.

Zhu,Y. and H. Gong.2014. Beneficial effects of silicon on salt and drought tolerance in plants. Agron. 